AUTOMOBILES

EXHAUST

1,3-BUTADIENE

SAMPLING
GASOLINE

VAPOR

ALKENES

CHROMATOGRAPHY

Open access reviewed manuscript version of Sci. Total Environ. 116 (1992) 195-201

\title{
Butenes and butadiene in urban air
}

\author{
Lars Löfgren and Göran Petersson \\ Department of Chemical Environmental Science, Chalmers University of Technology, \\ S-41296 Göteborg (Sweden)
}

Subsequent applied studies:

$\underline{\text { Road tunnels }}$

Commuter vehicles

Tobacco smoke

Domestic wood burning 
BUTENES AND BUTADIENE IN URBAN AIR

Lars Löfgren and Göran Petersson

Department of Chemical Environmental Science

Chalmers University of Technology

S-41296 Göteborg, Sweden

\section{ABSTRACT}

Samples of urban air hydrocarbons were taken on specifically made adsorbent cartridges and analyzed by gas chromatography after thermal desorption.The four isomeric butenes and 1,3-butadiene were favourably resolved and separated from the abundant alkanes on an aluminium oxide PLOT column.

The concentrations of butadiene, reflecting outdoor urban exposure, were in the range of $0.5-5 \mu \mathrm{g} / \mathrm{m}^{3}$. An approximate $1: 4$ ratio was observed between butadiene and propene which both originate predominantly from vehicle exhaust. The four butenes made up 50\% of the propene concentration in exhaust-polluted air, with methylpropene $>1$-butene $>$ trans-2-butene $>$ cis-2-butene. Petrol vapour contributed less than exhaust but about five times more to the 2-butenes than to methylpropene and 1-butene.

The highest exposure levels of butadiene and butenes were consistently observed in the vicinity of exhaust pipes and petrol-fuelled vehicles.

KEY WORDS: roads, automobiles, exhaust, petrol, alkenes, olefines, gas chromatography, exposure. 


\section{INTRODUCTION}

Health hazards attributable to alkenes have recently received attention with regard to the metabolic conversion of these hydrocarbons to genotoxic epoxides. In addition to ethene, propene (Svensson and Osterman-Golkar, 1984) and butadiene (Filser and Bolt, 1984) have been studied. Butadiene has been shown to be a carcinogen (Huff et al., 1985).

Alkenes in urban air are also of concern with respect to health because of their photochemical conversion to genotoxic products in the presence of nitrogen dioxide. Propene has been studied in some detail (Kleindienst et al., 1985) and butadiene appears to be even more potent in this respect (Victorin and Ståhlberg, 1988).

Knowledge of urban ambient concentrations and exposure levels of alkenes is clearly essential for the assessment and prevention of health hazards. Ethene and propene have been extensively measured, while there is very little consistent data on higher alkenes, mainly owing to analytical difficulties. The purpose of the present study is to provide data for butenes and butadiene. 


\section{EXPERIMENTAL}

Samples were taken on adsorbent cartridges coupled to personal sampling air pumps. The adsorbents were Tenax TA (60/80 mesh, Chrompack) in the front end, Carbotrap (20/40 mesh, Supelco) in the middle and Carbosieve S-III (60/80 mesh, Supelco) in the back-up end of glass tubes ( $150 \mathrm{~mm} \times 4 \mathrm{~mm}$ i.d.), in approximately equal amounts. The air volumes were in the range of $0.2-3$ litres per sample. Parallel samples were occasionally taken for quality control with cartridges containing only the well-known adsorbent Tenax TA.

In the laboratory, helium accomplished desorption at $235^{\circ} \mathrm{C}$ into a cool trap (liquid nitrogen) in the oven of a Carlo Erba 2900 gas chromatograph. The sample was injected onto a PLOT analytical column ( $50 \mathrm{~m} \times 0.32 \mathrm{~mm}$ i.d.) with $\mathrm{KCl}$-treated aluminium oxide as the stationary phase using electric heating of the trap. The oven temperature was raised $10^{\circ} \mathrm{C}$ per minute from $0^{\circ} \mathrm{C}$ to $110^{\circ} \mathrm{C}$, was kept constant for 14 minutes at $110^{\circ} \mathrm{C}$, and was finally raised $4^{\circ} \mathrm{C}$ per minute to $200^{\circ} \mathrm{C}$. Chromatogram, retention times and quantitative data were obtained from a reporting integrator. Response FID factors for the alkenes were set equal to that determined for $n$-heptane.

Further analytical data were given in a preliminary report (Nordlinder et al.,1984) on the performance of the aluminium oxide column obtained from Chrompack. A similar column was used in a study of hydrocarbons, including alkenes, in the air of a French rural area (Kanakidou et al., 1989) 


\section{RESULTS AND DISCUSSION}

\section{Chromatographic separation}

The chromatogram given in Fig. 1 illustrates the separation achieved for propene, butadiene and the four isomeric butenes. The alkenes $\left(C_{n}\right)$ appear in a favourable position between the $C_{n}$ and $C_{n+1}$ alkanes, which are present in much higher concentrations in urban air. With the proper choice of temperature program, butadiene separates from $n$-pentane. The aluminium oxide column also separates the four butenes well. On the commonly used non-polar stationary phases, 1-butene and methylpropene are normally not separated, and alkenes appear in the same region as the corresponding alkanes (Berglund and Petersson, 1990). The alkynes do not interfere with the alkenes, and oxygenated compounds are strongly retained by the aluminium oxide column. 


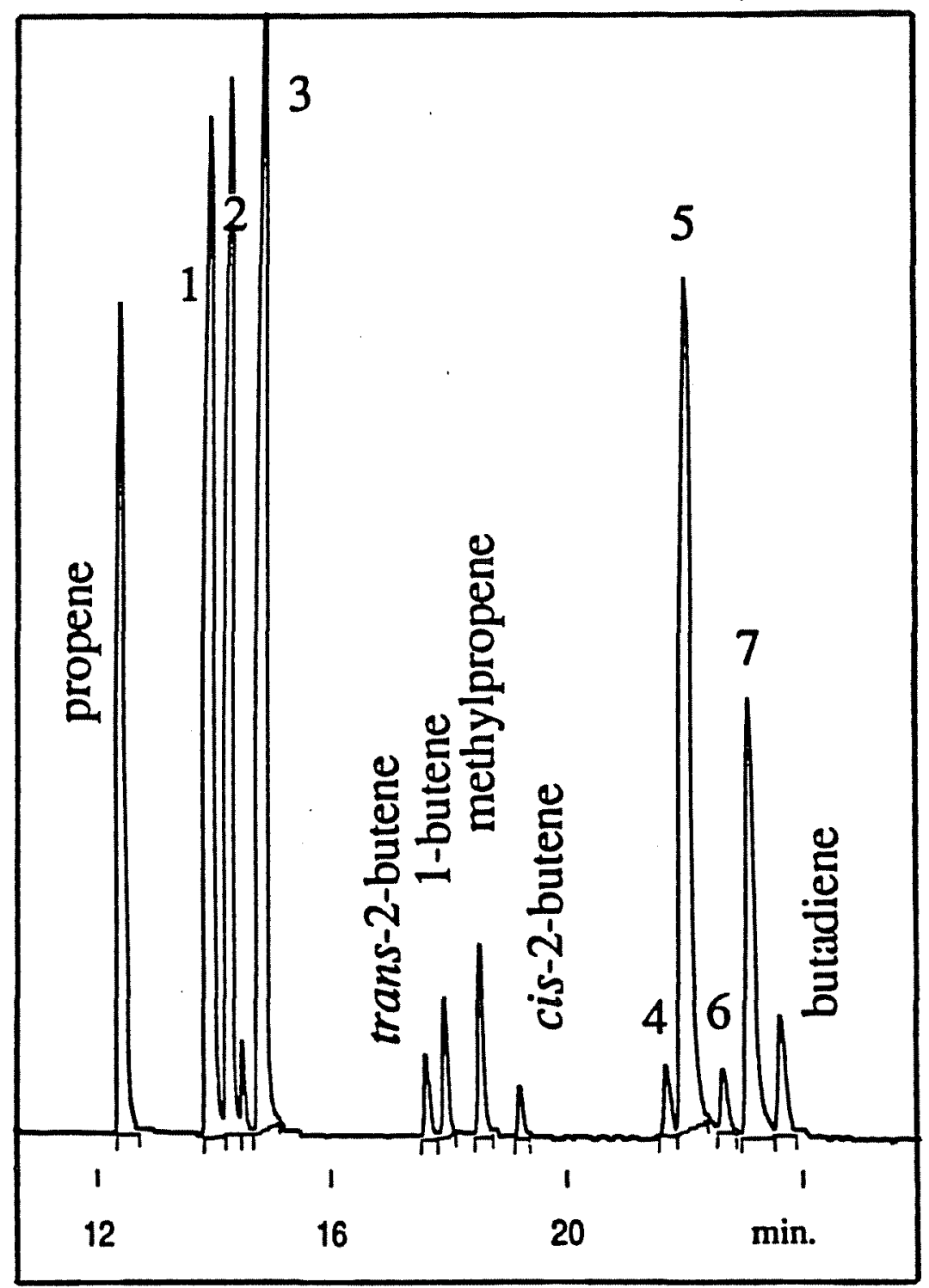

Fig. 1. Gas chromatographic analysis of $\mathrm{C}_{3}$ and $\mathrm{C}_{4}$ alkenes in urban air near a major road (1 ethyne, 2 methylpropane, 3 butane, 4 cyclopentane, 5 methylbutane, 6 propyne, 7 pentane). 
Concentration levels

The results given in Table 1 were selected as representative from a considerable number of urban air samples. The concentration levels and the concentration ratios between the hydrocarbons were checked by duplicate samples. Results for propene and butanes (methylpropane $+n$-butane) are included to permit comparisons with other studies reporting on these hydrocarbons.

The seven reported samples represent widely differing circumstances with respect to emissions, locality and meteorology. The urban background sample indicates low concentrations far from motor vehicles. The second sample from the parade street of Göteborg reflects near-average urban outdoor exposure. The third sample represents unfavourable winter inversion conditions near slow traffic and the fourth sample unfavourable summer conditions at the same, fairly typical, intersection. The fifth (Fig. 1) and sixth samples reflect ordinary winter and summer concentrations near to fast road traffic.The last sample represents intermediate indoor levels of a parking garage. Much higher concentrations were recorded under unfavourable conditions in large parking garages.

It is seen that the concentration of butadiene is $20-30 \%$ as compared with that of propene, and is similar to that of methylpropene. Among the four isomeric butenes, methylpropene is the most abundant and cis-2-butene the least abundant. 
Table 1. Representative concentrations of alkenes $\left(\mu \mathrm{g} / \mathrm{m}^{3}\right)$ reflecting human exposure in different environments.

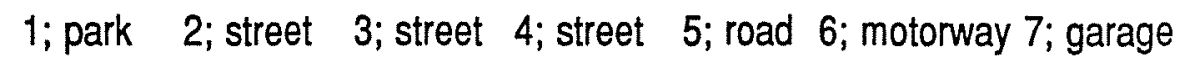
off-traffic esplanade crossing crossing plume roadside exit

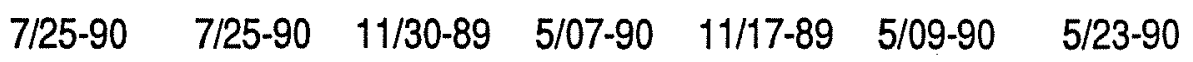

\begin{tabular}{llcccccc} 
Propene & 0.26 & - & 27 & 12 & 6.5 & 4.3 & 24 \\
Methylpropene & 0.09 & 0.7 & 7.7 & 3.2 & 1.5 & 0.7 & 7.5 \\
1-Butene & 0.07 & 0.4 & 5.2 & 2.4 & 1.0 & 0.5 & 4.7 \\
trans-2-Butene & 0.03 & 0.4 & 3.7 & 2.3 & 0.7 & 0.3 & 4.7 \\
cis-2-Butene & 0.03 & 0.3 & 3.1 & 1.8 & 0.5 & 0.2 & 3.7 \\
Butadiene & - & 0.6 & 6.1 & 2.9 & 1.6 & 0.9 & 7.4 \\
Butanes $\left(\mathrm{C}_{4}\right)$ & 2.2 & 26 & 160 & 85 & 21 & 8.8 & 155 \\
& & & & & & & \\
\hline
\end{tabular}

1- The Slottskogen park $2 \mathrm{~km}$ downwind central Göteborg and $500 \mathrm{~m}$ downwind traffic, $20^{\circ} \mathrm{C}$. 2- Walking along the Avenue of Göteborg, $20^{\circ} \mathrm{C}$. 3- Near intersection with traffic lights, $0^{\circ} \mathrm{C}$, inversion. 4- Same intersection, morning rush hour, calm and sunny, $20^{\circ} \mathrm{C} .5-$ Bridge $5 \mathrm{~m}$ above motorway approach to Göteborg, $0^{\circ} \mathrm{C}$. 6- E6 $(90 \mathrm{~km} / \mathrm{h}) 10 \mathrm{~km}$ south of Göteborg, $10^{\circ} \mathrm{C} .7$ - Inside parking garage near cars leaving in the morning, $15^{\circ} \mathrm{C}$. 
Sources of butenes and butadiene

In urban outdoor air, the hydrocarbons assessed here originate predominantly from petrol vapours and exhaust from petrol-fuelled vehicles. As illustrated in Table 2, the composition is very different for exhaust and vapours. The figures are based on the results of exhaust samples and on previous studies of petrol vapours (Berglund and Petersson, 1990). An Australian study reports similar differences in the composition of the four butenes (Nelson et al., 1983). From Table 1, it is evident that petrol exhaust is the major source of alkenes throughout. The increased proportion of butenes, particularly 2-butenes, for the fourth sample is attributed to an increased proportion of vapours at high ambient temperatures. The similar composition for the garage sample may be explained by the higher emissions of unburnt petrol from cold engines. The increased proportion of alkenes, particularly propene, as compared with butanes for the road samples is explained by the increased proportion of lower alkenes in exhaust at elevated speeds (Bailey et al., 1990).

It is concluded that petrol vapours and exhaust are sources of a similar magnitude for the 2-butenes in urban air. For methylpropene and 1-butene, the proportion from vapour is $\sim 10 \%$. For both butadiene and propene, the contribution from petrol vapour is negligible as compared with exhaust. In hotter climates, the proportion of butenes from petrol vapours is greater (Nelson et al., 1983). 
Table 2. Representative percentual composition of $\mathrm{C}_{3}-\mathrm{C}_{4}$ alkenes in petrol exhaust and vapour.

\begin{tabular}{lrr}
\hline & Exhaust & Vapour \\
\hline Propene & 60 & 0 \\
Methylpropene & 12 & 20 \\
1-Butene & 8 & 15 \\
trans-2-Butene & 4 & 35 \\
cis-2-Butene & 3 & 30 \\
Butadiene & 13 & 0 \\
\hline
\end{tabular}

Human exposure

Health hazards with respect to metabolic formation of genotoxic epoxides should be directly related to the exposure levels of the alkenes. Particular attention should be paid to the carcinogenic butadiene from vehicle exhaust. High exposure levels in situations where many people are exposed should be of special concern.

The reported samples focus on the comparatively high concentrations in the vicinity of petrol-fuelled vehicles. At the time of this study about $20 \%$ of these vehicles were equipped with catalytic converters in Sweden. With increasing distance from exhaust-emitting vehicles, more than a tenfold decrease of the concentrations of exhaust 
hydrocarbons were recorded. Motorists are exposed at least to the roadside levels but also to irregular additional contributions from their own cars. These findings conform with previous exposure-related studies of $\mathrm{C}_{5}-\mathrm{C}_{10}$ exhaust hydrocarbons using a similar analytical technique (Mattsson and Petersson, 1982).

When indoor exposure is considered, it is important to include environmental tobacco smoke. High levels of butadiene as well as propene are reported from this source (Löfroth et al., 1989). 


\section{REFERENCES}

Berglund P.M. and Petersson G. (1990) Hazardous petrol hydrocarbons from refuelling with and without vapour recovery. Sci.Total Environ. 91, 49-57.

Filser J.G. and Bolt H.M. (1984) Inhalation pharmacokinetics based on gas uptake studies. VI. Comparative evaluation of ethylene oxide and butadiene monoxide as exhaled reactive metabolites of ethylene and 1,3-butadiene in rats. Arch. Toxicol. 55, 219-233.

Huff J.E., Melnick R.L., Solleveld H.A., Haseman J.K., Powers M. and Miller R.A. (1985) Multiple organ carcinogenicity of 1,3-butadiene in $\mathrm{B}^{6} \mathrm{C} 3 \mathrm{~F}_{1}$ mice after 60 weeks of inhalation exposure. Science 227, 548-549.

Kanakidou M., Bonsang B. and Lambert G. (1989) Light hydrocarbons vertical profiles and fluxes in a French rural area. Atmos. Environ. 23, 921-927.

Kleindienst T.E., Shepson P.B., Edney E.O., Cupitt L.T. and Claxton L.D. (1985) The mutagenic activity of the products of propylene photooxidation. Environ. Sci. Technol. 19, 620-627.

Löfroth G., Burton R.M., Forehand L., Hammond S.K, Seila R.L., Zweidinger R.B. and Lewtas J. (1989) Characterization of environmental tobacco smoke. Environ Sci. Technol. $\underline{23}$, 610-614. 
Mattsson M. and Petersson G. (1982) Trace analysis of hydrocarbons in air using standard gas chromatographic and personal sampling equipment. Intern. J. Environ. Anal. Chem. 11, 211-219.

Nelson P.F., Quigley S.M. and Smith M.Y. (1983) Sources of atmospheric hydrocarbons in Sydney: A quantitative determination using a source reconciliation technique. Atmos. Environ. 17, 439-449.

Nordlinder R., Ramnäs O. and Åmand L.-E. (1984) Analysis of $\mathrm{C}_{1}-\mathrm{C}_{9}$ hydrocarbons in environmental air. Chrompack News, $11: 4 \mathrm{E}$.

Svensson K. and Osterman-Golkar S. (1984) Kinetics of metabolism of propene and covalent binding to macromolecules in the mouse. Toxicol. Appl. Pharmacol. 73, 363-372.

Victorin K. and Ståhlberg M. (1988) Mutagenic activity of UV-irradiated mixtures of nitrogen dioxide and propene or butadiene. National Swedish Environmental Protection Board, Report 3519, 149-166. 